\title{
Utopie dotknięcia obrazem i słowem
}

Piotr Michałowski

TEKSTY DRUGIE 2021, NR 3, S. 134-142

DOI: $10.18318 /$ td.2021.3.10 | ORCID: 0000-0002-8716-9655

Piotr Michałowski

- literaturoznawca,

krytyk, eseista,

tłumacz, poeta.

Autor książek, m.in.

Miniatura poetycka

(1999), Granice poezji

i poezja bez granic

(2001), Glosy, formy,

światy. Warianty poezji nowoczesnej (2008),

Mikrokosmos wiersza.

Interpretacje poezji

współczesnej (2012).

W 2021 roku ukaże się

zredagowana przezeń

praca zbiorowa

Niepospolite ruszenie

słów. Liryka Heleny

Raszki w zbliżeniach

i przekrojach oraz

tomik poetycki Dzień jest wierszem, świat

kolorem. 
ontologię, omawia na interesująco dobranych przykładach sztuki polskiej Agata Stankowska'. Interpretacje zamieszczone w jej książce składają się na przegląd różnych prób niemożliwego „dotknięcia” sfer niedotykalnych, a wyjątkowo dotkliwych: doświadczeń Holokaustu i Traumy.

Tło rozważań i zarazem punkt wyjścia stanowi opozycja ikonoklazm ikonofilia, ale antynomiczność tych pojęć zostaje nie tyle przezwyciężona, ile na różne sposoby zrelatywizowana - zależnie od ideologii artystycznych, a zwłaszcza indywidualnych dokonań twórców. Ikonoklazm - średniowieczny ruch zwalczający obrazowe przedstawienia Boga jako niemożliwe i prowadzące do herezji czczenia samych obrazów - w XX stuleciu powrócił, zmieniając swój przedmiot na nieprzedstawialność Holokaustu. Może mieć jednak dwa źródła i przeciwne wektory motywacji: albo wypływa z estetyzmu, albo z historycyzmu, to znaczy albo podważa historię, albo odrzuca obraz z powodu jego specyficznych cech formalnych. Paradoksalną odmianą ikonoklazmu okazuje się nowoczesna forma ikonofilii zdiagnozowana przez Różewicza i Baudrillarda postrzegających kulturę wizualną jako dewaluację obrazu wskutek jego nadprodukcji.

Hasłem dopełniającym siatkę pojęć jest „sztuka nieczysta”, która, jak zauważa badaczka, była reakcją na modernistyczną ideę autonomii i wyjściem poza sferę artystyczną, a performatywne zaangażowanie w proces recepcji sprawiło, że równie ważny jak samo dzieło stał się akt patrzenia. Przekraczanie granic "czystości” zachodzi jednak w tendencjach rozbieżnych: w sztuce niefiguratywnej z taszyzmem na czele, surrealizmie i ready made, choć jedynie ten ostatni nurt wydaje się ściśle odpowiadać zasadzie uobecnienia. Proces odbioru wzrokowego bowiem, jako oparty na zmysłach, ma podstawy biologiczne, ale ponadto uaktywnia intelekt i emocje, zastępując uobecnianie przedmiotu psychosomatyczną reakcją widza. Z takim przesunięciem istoty sztuki wiąże się kolejna kategoria, preposteryjność, polegająca na tym, że artefakty późniejsze warunkują sposób, w jaki odczytujemy wcześniejsze; następuje zatem prezentystyczna aktualizacja tego, co historyczne i „odwrócenie relacji między kontekstem macierzystym a aktualnym celem czytania, między zamiarem rekonstrukcji historycznego znaczenia tekstu a pytaniem o efekt jego współczesnej, zaangażowanej, afektycznej lektury [...] Przeszłość jest stwarzana przez współczesność” (s. 39-40). Narzuca to z kolei „nieczystość praktyki badawczej" polegającą na odrzuceniu zarówno ikonologii,

1 A. Stankowska Ikona i trauma. Pytania o "obraz prawdziwy" w liryce i sztuce polskiej drugiej połowyXX wieku, Universitas, Kraków 2019. 
jak lingwistycznej systemowości lektury obrazu. Metodologiczne podstawy koncepcji historii preposteryjnej dają prace Christiana Boltanskiego i Ydessy Hendeles, które obok innych zainspirowały autorkę Ikony i traumy do niezwykle przenikliwych interpretacji, choć te swój rozmach i głębię zawdzięczają przede wszystkim jej wrażliwości i kompetencjom obejmującym interdyscyplinarną wiedzę z zakresu literaturoznawstwa i historii sztuki.

Wybranymi bohaterami książki są: Tadeusz Różewicz, Tadeusz Kantor, Jerzy Nowosielski, Stanisław Czycz i Ewa Kuryluk, reprezentujący różne dziedziny artystyczne, jednak centrum dociekań stanowi nie refleksja intersemiotyczna, lecz rola doświadczenia traumatycznego i próby jego zapisu, który różnymi drogami dąży do przekroczenia granic ekspresji, powodując „spięcia między poczuciem bezradności a konieczności, grę między sztuką zerową a konwencjami” (s. 9). Zaplecze teoretyczne imponujących studiów przypadków stanowią teorie, poglądy i polemiki m.in. Beltinga, Danto, Bal, Baumana, Didi-Hubermana. Zrelacjonowane zmagania artystów z niewyrażalnym tworzą wprawdzie mozaikę varietas, ale także ujawniają pewne sekwencje nakładających się zagadnień, gdyż niemal każda próba splata się z inną, prowokując nowe pytania badaczki, a te z kolei skłaniają czytelnika do rozszerzającego egzemplifikację suplementowania, polemik i pomnażania stawianych przez autorkę kwestii na marginesach inspirującej lektury.

Przegląd postaw artystycznych otwiera rozdział Ikonoklazm odwrócony. Tadeusz Różewicz w poszukiwaniu form "wewnętrznego obrazu” i tu w wywodzie następuje nie całkiem prawomocny ześlizg tematyczny. Przedmiotem rozważań staje się bowiem obraz poetycki i metafora, a nie przedstawienie wizualne; a przecież to, co wykreowane słowem, bliższe jest jednak narracji (opisowi) niż będącemu źródłem doznań sensorycznych obrazowi plastycznemu - mimo innej deklarowanej intencji twórcy. Jeśli w problematykę ikonoklazmu włącza się zagadnienie obrazu poetyckiego, to agon toczy się już wyłącznie w obszarze pośredniczącego języka werbalnego, stając się sporem o metodę poetycką, takim jak polemika Różewicza z Przybosiem, której przedmiotem jest „metafora-obraz” i cel poezjowania. Badaczka zresztą tę dystynkcję dostrzega, choć nie zaznacza, że chodzi tu jedynie o narracyjne metauobecnianie:

To, co niewyrażalne i traumatyczne, istnieje [...] w tym, co somatyczne i dotykalne, a nie wyobrażone i wykreowane. Obrona poetyckich przedstawień prowadzi w myśleniu poety w kierunku takiej ich modyfikacji, 
by wydobyć ową swoistą somatyczną przyległość obrazu (metafory) do przedmiotu traumatycznego doświadczenia. (s. 66)

Dalej stwierdza, że Różewicz rozwija teorię „wewnętrznego obrazu”, do którego należy raczej docierać niż go tworzyć. Niemniej dodać trzeba, że podobnie jak w przypadku poetyckiej narracji, ,dotknięcie" rzeczywistości zawsze staje się tylko mniej lub bardziej sugestywnym opisem - niezależnie od tego, jakimi ten akt zostanie obwarowany zastrzeżeniami co do kierunku wyobraźni i referencji. Dlatego niemożliwość „dotknięcia” powinna być zauważona i zdemistyfikowana już na wstępnym etapie analizy, gdyż „uobecnianie” rzeczywistości językiem to stara utopia - poza eksperymentami poezji konkretnej. Różewicz, wprawdzie genialnie, ale jednak tematyzuje swe pragnienie "dotknięcia” w metapoetyckich i autotematycznych opowieściach o niemocy spełnienia tego aktu. Poszukiwany przezeń idiolekt ma być negacją języka poetyckiego, a więc również krytyką estetycznego odbioru. Destylowany w ten sposób kod cierpienia pozostaje nieokreślony. Tym samym „wewnętrzny obraz" istnieje w sferze implikacji - jako milczenie opowiedziane, a nie uobecnione. Różewicz porusza się po błędnym kole niemocy: jak przywołać „bezpośrednio” cokolwiek, odrzucając ideę przedstawiania i obrazu?

Autorka przyznaje zresztą, że wiersz Różewicza stanowi próbę nie tyle uobecnienia, ile uobecniającej lektury obrazu, która kieruje uwagę widza na spełniający się dramat. Natomiast świadomość ograniczeń w plastyce mających już inny charakter - poeta wyraża w poemacie Spadanie, dokonując krytyki zdesakralizowanej sztuki współczesnej. Przywołany przezeń film Mondo Cane Jacopettiego i Cavary zawiera motyw zawłaszczania veraikonu przez odciskane na płótnie „żywe pędzle” Kleina, czyli ciała modelek, które mają być metonimicznym symptomem rzeczywistości.

Omówiony w książce przypadek Różewicza jako krytyka niedosiężnej idei "uobecniania" wydaje się swoistą metanarracją wobec omawianych potem postaw artystycznych: choć żadnej z nich nie można przypisać naiwno-awangardowego optymizmu, na wszystkie projekty pada cień jakiegoś zwątpienia. Rozdział Bolesny urok surrealizmu. Tadeusz Kantori Stanisław Czycz o kryzysie obrazu i stowa opowiada o twórcach, którzy próbują

ograniczyć sztuczność sztuki jako domeny estetyki [...] takim sposobem bycia w sztuce, które pozwoliłoby przekroczyć granice wszelkich artystycznych konwencji lub przynajmniej [...] wykorzystać je z defektem 
świadczącym o egzystencjalnym, a nie estetycznym motywie działania tych, którzy konwencjami się posługują. (s. 104)

Konfrontując idee awangardowego przedstawiania z wysiłkiem neoawangardowego uobecniania, warto jednak zwrócić uwagę, że mowa tu przede wszystkim o inten cji, a więc raczej o towarzyszących aktom tworzenia a fek t a ch, niekoniecznie zaś ef ekt a ch, które często powodują nieporozumienia w odbiorze. To, co na poziomie idei zostaje wyraźnie zdefiniowane, w recepcji ulegać może rozmazaniu, a dotyczy to zapewne w większym stopniu zwiedzania galerii niż lektury książki. Pośród przekonującej argumentacji z użyciem takich kategorii, jak powód czy motywacja, zabrakło jednak kluczowego pytania o czytelność konterfektów jako „śladów”, które odcięte od genezy stają się zagadką - niekiedy podobnie osamotnioną jak wiele eksponatów archeologicznych z paleolitu.

Obaj twórcy w jakimś stopniu włączają się w nurt surrealistyczny, jak zauważa autorka, niesłusznie w poezji polskiej marginalizowany. Ich krytyczny stosunek do awangardowego konstruktywizmu motywowany był jednak inaczej niż u Ważyka: poczuciem rozpadu i śmierci kultury. Stąd w twórczości Czycza wybrzmiewają „echa katastroficzne”, ale znów polemicznie - zarówno wobec „Czechowiczowskiej sielanki” jak „żagarystowskiej nadziei”. Zdaniem badaczki (a wbrew tezom Kazimierza Wyki i Jerzego Kwiatkowskiego) autor Tet pozostał pozbawionym nadziei na ocalającą moc poezji „podmiotem traumatycznym", czego przekonująco dowodzi analiza wiersza Brama - jako "afektywnego powtórzenia" doznań więźniów KL Birkenau. Oczywiście, "somatyczne powtórzenie niewłasnego bólu" jest doświadczeniem niedostępnym, toteż poeta podejmuje próbę rekonstrukcji cierpienia inną drogą i

stawia nie tyle na odzwierciedlenie podświadomych warstw psychiki, ile na automatyczne powielanie stanu emocjonalnego podmiotu w tekście, dla którego znaki dostarcza percepcja podprogowa: nieświadomie zapamiętane fragmenty otoczenia, ułomki fraz, słów, przedmiotów, pejzaży, melodii. Wegetatywne widzenie ważniejsze jest od racjonalnego obrazu. Doznanie od poznania. Automatyzm od kreacji. (s. 120)

Najciekawsze próby uobecnienia traumy znajdujemy jednak w dokonaniach twórców uprawiających równolegle kilka dziedzin sztuki, które próbują albo ze sobą synkretycznie łączyć, albo skonfrontować, wyznaczając im odmienne cele i horyzonty wyrażania niewyrażalnego. Wnikliwe analizy 
dokonań Kantora obejmują jego ambalaże, twórczość teatralną i metateatralną, w tym również manifesty zapisywane z podziałem na wersy, co pozwala badaczce - może nie całkiem zasadnie - uznać je za poezję. Istotna jest dwutorowość tekstu i niezależnej od niej akcji, a także dwutorowość iluzji i "gotowej" rzeczywistości, gdyż konfrontacja tych składników eksponuje ich nietożsamość. Z kolei w ambalażach toczy się gra między odsłaniającym "dotknięciem” a chroniącym przed przedstawianiem „ukryciem”. Wreszcie w teatrze aktor staje się zarazem narzędziem i rzeczywistym bytem, który wnosi swoją fabułę. Kantorowi chodzi nie o prawdę widzenia, lecz o prawdę istnienia, jednak wszystkie zanalizowane eksperymenty dowodzą wszechstronności krytycznej refleksji twórcy Cricot 2, będącego nie tylko oryginalnym artystą, lecz także wielkim teoretykiem sztuki.

W centrum dyskursu dość nieoczekiwanie sytuuje się konfrontacja stanowisk Różewicza konstatującego bezsens cierpienia w „rzeźni”, wykazującego brak empatii, i Nowosielskiego, który manifestuje „sztukę budującą”, lecz mimo zainteresowań ikoną stroni od symboliki. Sens opozycji wyeksponowanej w tytule książki przemieszcza się tym samym na problem etyki przedstawienia i chodzi tu już o coś innego niż antynomia: reprezentacja - uobecnianie. Dialog prowadzony w korespondencji i samej twórczości przyjaciół toczy się właściwie w oderwaniu od różnicy profesji: poety i malarza (który jednak jest również eseistą i historykiem sztuki). Chrześcijańska perspektywa zmartwychwstania po katastrofie (u Nowosielskiego) albo jej odrzucenie i odczucie dotkliwego braku (u Różewicza) to stanowiska rzeczywiście biegunowe, co świetnie zostało udokumentowane oraz przekonująco skomentowane. Szkoda jednak, że postawy Nowosielskiego nie wspiera szersza egzemplifikacja, przez co wydaje się ona marginalna i odosobniona: „Spojrzenie, jakie proponuje Nowosielski, stawiając znak równości między sztuką a chwała, łączy się z restytucją przednowoczesnego myślenia o dziele malarskim, którego rola jest w tej pierwszej optyce powiązana ściśle z praktykami symbolicznymi i z kultem" (s. 180). Autor Zagubionej bazyliki próbuje odtworzyć pierwotną jedność sztuki z liturgią i estetyki z teologią, ale zmierza do tego dwiema na pozór rozbieżnymi drogami. Pierwszą jest malarstwo figuratywne, nawiązujące do tradycji ikony, drugą - abstrakcja z wychyleniem spirytystycznym, która ma być zapisem naszej wyobraźni. Paradoksalnie, obie prowadzą do okna otwartego na to, co Nieprzedstawialne, i wychodząc od tej samej intencji - mimo przeciwnych wektorów - stanowią przejście od empirii do transcendencji. Nowosielski próbuje osiągnąć równowagę między sztuką „zstępującą” (sakralną) a „wstępującą” (świecką). Co ciekawe, 
w jego autorskim paradygmacie ikony mieszczą się również pejzaże i akty kobiece, w których nagromadzenie elementów biologicznych wprowadzać ma na wyższe piętro świadomości, natomiast przeciążenie nimi sprawia, że obraz przestaje być ikoną.

Artystką działającą w obszarze dwóch dziedzin: poezji i wielu technik plastycznych jest Ewa Kuryluk, u której dopełniają się one programowo: „Piszę, czego nie mogę narysować, rysuję, czego nie mogę napisać”, choć w jakimś stopniu wiersze narzucają interpretację obrazów. Tytuł rozdziału pseudonimuje główny dylemat omawianych w całej książce wysiłków sztuki: Apokalipsa i utopia. Że chodzi o utopię, w pełni się zgadzam, natomiast apokalipsa jako synonim katastrofy i Zagłady, mimo „nietykalności” tych świętych odniesień, wydaje się jednak potocznym nadużyciem, gdyż lektura Objawienia św. Jana, doprowadzona do końca, odnaleźć powinna jednak optymistyczny finał dziejów świata - bliższy koncepcji Czechowicza i przysłowiu per aspera ad astra. Zwłaszcza że, jak czytamy, źródłem wielu obrazów Kuryluk jest ból po stracie i lęk przed możliwą utratą, a nie absolutny koniec wszystkiego.

Autorka Weroniki i jej chusty, zbiorów poetyckich Kontur i Pani Anima, obrazów malarskich, grafik, fotografii, autokolaży i somatycznych Człekopejzaży reprezentuje dwa zbieżne, ale nie tożsame sposoby myślenia o sztuce: cień/kontur albo odbicie/odcisk. Wykonany przez nią obrys własnego cienia jest uchwyceniem jednej chwili konkretnego obiektu i zarazem podmiotu. Tu warto zauważyć (co nie podważa wartości eksperymentu Kuryluk), że działanie to bliskie jest innym metodom utrwalania postaci, nie tylko ironicznie pokazanym w Mondo Cane, lecz także praktykowanym w sztuce pamiątkarskiej, raczej turystycznej niż traumatycznej; przykładem byłyby podobne do cienia portretowe profile à la minute wycinane z czarnego papieru na Place du Tertre na Montmartre, choć są one odwzorowaniem, które dokonuje się bez dotknięcia innego niż tylko wzrokiem. Natomiast fotografię można już bardziej dosłownie uznać za fizyczne dotknięcie - światła, a przez nie utrwalanej rzeczywistości. Lepszym przykładem mogą być odciski linii papilarnych albo dłoni pozostawione na promenadach czy w alejach gwiazd, choć są śladem chwały, a nie cierpienia. Jednak ta droga rozumowania prowadziłaby do wniosku, że najbardziej radykalnym veraikonem traumy byłby skrajny wariant body art - zmumifikowane ciało.

Zamknięciem rozważań jest rozdział Zakazane fotografie. O ikonoklazmie $w$ dyskursie holokaustowym. Chodzi tu jednak już nie o sztukę, lecz o zdjęcia dokumentalne i związany z nimi paradoks: pierwszy zakaz wykonywania zdjęć lagrów wydali sprawcy, by uniknąć dowodów swych zbrodni, przez co 
ikonoklazm późniejszy, prowadzony w obronie pamięci ofiar i z pobudek estetyczno-etycznych, staje się dwuznaczny. Jednak pisanie o nazistach jako jedynych strażnikach milczenia wokół Holokaustu jest mylącym uproszczeniem i lepiej byłoby założyć, że i dawniej, i dzisiaj strażnikami są animatorzy polityki historycznej. Warto byłoby także odstąpić od zasady political correctness na rzecz uczciwej faktografii (choćby w imię skądinąd propagowanej "całej prawdy" i w kontekście krytyki ujęć redukcyjnych), wskazując wprost naród, który nazizm stworzył, zwłaszcza że jego nazwę zastępują peryfrastyczne hasła: „,rasizm”, „Aryjczyk” i „nadczłowiek”. W trosce o pamięć przyszłych pokoleń dopowiem więc to, czego autorka skrupulatnie unika: chodzi o Niemców. To chyba ważne, zwłaszcza jeśli obóz w Sobiborze lokalizuje się „w Polsce” (zamiast: w Generalnej Guberni).

Referując dyskurs wokół przedstawień Zagłady, autorka wskazuje na aporetyczność sporu, w którym zajęcie niemal każdego stanowiska oznacza ryzyko zarzutów z różnych stron. Niektóre aspekty polemik uwypukla, natomiast inne pomija i szkoda, że powstrzymuje się od komentarza w sprawie, zdawać by się mogło, oczywistej, a dotyczącej istoty wszelkiej ikoniczności. Chodzi o zarzuty stawiane fotografiom z Auschwitz, którym odmawia się prawa reprezentacji Holokaustu, ponieważ „nie mówią wszystkiego”. Można zapytać z niechętnie w tym dyskursie dopuszczanym obiektywizmem teoretyka: czy w jakimkolwiek innym odniesieniu podobna teza nie byłaby naukową herezją lub absurdem? Czy wyłącznie w tym przypadku wolno abstrahować od swoistości medium i nie dostrzegać, że istotą każdej fotografii jest nieunikniona synekdochiczność - ukazanie fragmentu? Domaganie się "całej prawdy” w obrazie niesymbolicznym i niealegorycznym to idealistyczne urojenie, które implicite podważa wartość każdego obrazu i każdego dokumentu próbującego utrwalić dowolną rzeczywistość, niekoniecznie traumatyczną. Trzeba skonstatować z żalem (i bez intencji prowokacji), że dyskurs holokaustowy odrywa się od uniwersalizującej teorii sztuki, szukając osobnej metodologii - niepodległej i autonomicznej, a więc na własny sposób „czystej”. Autorka nie postrzega tego problemu tak radykalnie, ale słusznie optuje za demokratyzacją doboru środków artystycznego wyrazu, postulując (może zbyt nieśmiało) „metakrytyczny namysł nad ograniczeniami właściwymi każdej konwencji” (s. 262). Ostrożność, z jaką rewiduje się stanowiska, zresztą nie tylko „ikonoklastyczne”, w dyskursie holokaustowym, roszczącym sobie prawo do uprzywilejowanej pozycji poza teorią i logiką, wynika z presji opacznie pojętej poprawności politycznej, która sprawia, że jakikolwiek przejaw inwencji, eksperymentu wybiegającego poza kanoniczne (?) formy 
upamiętniania może zostać uznany za wykroczenie etyczne. Skłonność do cenzurowania przedstawień Zagłady niezgodnych z dogmatem „całej prawdy” i zakazem estetyzacji wskazuje badaczka pośrednio - przytaczając przykład Różewicza, który spotkał się z zarzutami krytyków, kiedy w nożyku profesora zamieścił przetworzoną artystycznie fotografię dokumentalną z obozu w Sobiborze. Stankowska broni poety, trafnie odczytując jego intencję: chodziło o to, by wzbudzić u odbiorcy refleksję nad statusem przedstawienia. Niemniej tabuizacja wielu form, ograniczająca (poadornowskim nakazem milczenia i dogmatem „niewyrażalności”) swobodę poszukiwań artystycznych, zarówno obrazowych, jak narracyjnych, doprowadziła do stanu nietolerancji, który powinien stać się przedmiotem osobnych (nieocenzurowanych) rozważań.

\section{Abstract}

\section{Piotr Michałowski}

UNIVERSITY OF SZCZECIN

Utopias of Touch by Word and Picture

Review: Agata Stankowska, Ikona i trauma: Pytania o „obraz prawdziwy" w liryce i sztuce polskiej drugiej połowy XX wieku [Icon and Trauma: Questions About the "True Image" in Polish Poetry and Art in the Second Half of the Twentieth Century], Universitas, Cracow 2019 (Modernizm w Polsce, vol. 63).

\section{Keywords}

veraikon, icon, Shoah, Holocaust, twentieth-century Polish art and poetry 